\title{
Knowledge and Compliance of Nursing Students regarding Infection Control Standard Precautions during their Clinical Training
}

\author{
Manal Abdalla Sayed Ahmed Gaheen ${ }^{1}$, Entisar AboElghite Elhossiny Elkazeh ${ }^{2}$, and \\ Amaal Mohamed Ahmed El-Zeftawy \\ 1 Maternity and Gynecological Nursing Department, Faculty of Nursing, Tanta \\ University, Egypt., \\ ${ }^{2}$ Community Health Nursing Department, Faculty of Nursing, Tanta University, Egypt. \\ ${ }^{3}$ Community Health Nursing Department, Faculty of Nursing, Tanta University, Egypt.
}

Background: Infection is one of the most important problems in health care services worldwide; also, it constitutes one of the most important causes of morbidity and mortality associated with clinical, diagnostic and therapeutic procedures. Nursing students are more exposed to infections duringtheir clinical training, so they need to improve their performance related to infection control measures. Standard precautions are set of measures formulated to prevent transmission of blood borne pathogens when providing health care. Aim of the study: Assess knowledge and compliance of nursing students regarding infection control standard precautions during their clinical training. Study design: An analytic comparative cross-sectional study was used for this study. Subjects and method: The study was conducted on 450 nursing studentsof second, third and fourth academic yearsat the Faculty of Nursing Tanta University. Toolsof data collection: Tool I: Structured questionnaire sheet which consisted of two parts. Part 1: - Socio-demographiccharacteristics of the nursing students. Part 2: -Standard precautions knowledge. Tool II: Part 1: Used for measuringcompliance with standard precautions. Part 2: measuring factors affecting the compliance with standard precautions. Results: The mean of ages of the studied students were $20.21 \pm 0.619,21.67 \pm 1.047$, and $21.74 \pm 0.65$ years for second, third and fourth academic years respectively. The total mean scores of knowledge were $(13.04 \pm 3.072,13.55 \pm 1.144$, and $12.24 \pm 2.579)$ respectively. The total compliance score in the studied group were $30.91 \pm 5.844$, $30.75 \pm 3.183$ and $29.67 \pm 5.142$ in the second, third and fourth years of students respectively. Also majority $(89.3 \%, 94.7 \%$ and $82.7 \%$ respectively) of the studied groups (second, third and fourth years) had good practice score of compliance, also there werea statistical significance difference between the levels of knowledge scores and also between the levels of compliance scores $\mathrm{P}<0.05$. Conclusion and recommendations: This study showed that there was statistically significance difference in relation to total score of knowledge and compliance score in the three studied years. However, the periodic refresher in-service training courses and regular lectures should be provided to nursing students in order to keep them of updating knowledge and practice regarding standard precaution measures.

Key words: Infection Control, Knowledge, Clinical training, Compliance, Standard Precautions

Vol. 20 No. 1 (Suppl) February, 2021 


\section{Introduction:}

Nosocomial infection (NI), or hospitalacquired infection or Health-CareAssociated Infection (HCAI) refers to infection that is acquired during the process of care providing and not manifested at the time of hospital admission or other health-care facility ${ }^{(1-3)}$. About $5 \%-10 \%$ of patients admitted to acute care hospitals in developed countries acquire $\mathrm{HCAI}$ at any given time, and the risk of acquiring infection is $2-20$ times higher in developing countries ${ }^{(4)}$. It constitutes a global health problem, and is considered as one of the leading causes of increased morbidity and mortality such as,prolonged hospitalization /Intensive Care Unit (ICU) stay; increased severity of the underlying illness; increased utilization of devices for monitoring and treatment; increased cost of treatment in both developed and developing countries; and impairment of the quality of patient's and family's life ${ }^{(5-7)}$.Health care professionals are constantly exposed to blood and other body fluids in the course of their work specially at delivery room and operating room. Hence, they are at a higher risk of acquiring infections such as human immune virus (HIV), Hepatitis B, and Hepatitis $\mathrm{C}$ etc. Occupational exposure to blood can result from percutaneous injury (needle stick or other sharps injury), mucocutaneous injury (splash of blood or other body fluids into the eyes, nose or mouth), or contact with non-intact skin. According to the WHO, out of 35 million health workers worldwide, about 3 million receive percutaneous exposures to blood borne pathogens each year; two million of those to HBV, 0.9 million to hepatitis $\mathrm{C}$ virus (HCV) and 170000 to HIV. These injuries may result in 15000 (HCV), 70 000 hepatitis B virus (HBV) and $500 \mathrm{HIV}$ infections. More than $90 \%$ of these infections occur in developing countries. Nursing students are also at risk of such infections and injuries due to accidental contamination during their practical occupational exposure $^{(7-10)}$.

Exposure to infectious material can be minimized by adherence to standard precautions which are designed to reduce the risk of acquiring occupational infection from both known and unexpected sources in the healthcare setting ${ }^{(8,9)}$. Standard precautions are set of measures formulated to prevent transmission of any type of pathogens when providing health care. Since identification of patients infected with these pathogens cannot be reliably made by medical history and physical examination, in 1996, the Centers for Disease Control (CDC) included the universal precautions in a new prevention concept the so-called "standard 
precautions", which are devised to be used for providing care of all patients in hospitals regardless of their diagnosis or presumed infection status, now replace the "universal precautions." The fact that "standard precautions" are recommended for the care delivery to all patients, regardless of their presumed infection state, it is important when handling equipment and devices that are contaminated or suspected of contamination with blood, body fluids, secretions and excretions except sweat, Standard precautions include hand washing; use of barriers (e.g., gloves, gown, cap, mask); care with devices such as fetal external and internalfetal monitoring, insertion of intrauterine device (IUD's), insertion of cannula and injections, equipment and clothing used during care; environmental control (e.g., surface processing protocols, health service waste handling); adequate discarding of sharp instruments including needles ${ }^{(11-13)}$.

All standards of care provide a guide to the knowledge, skills, judgment and attitudes that are needed to practice safely. They describe what each nurse is accountable and responsible for practice. The aim of standard of Infection Control (IC) precautions is to prevent HCAI (14). Infection control standards become an integral part of the accreditation program for all medical settings in Egypt, where the National Guidelines for Infection Control" (NGIC) are produced and established by the infection control team at the Ministry of Health \& Population (MOHAP) since the year $2003^{(15-17)}$.Therefore, adequate nursing staff is necessary because a higher patient-to nurse ratio increases the risk of nosocomial infection ${ }^{(18)}$.

Compliance is the extent to which certain behavior such as; following physician's orders or implementing healthier lifestylescan be influenced or controlled by a variety of factors like culture, economic and social factors and self-efficacy. Guidelines that guide an individual's behavior exist in a variety of settings including health care settings, but people do not always comply with them (19-21). Studies have shown that compliance with precautions among nurses in order to avoid exposure to microorganisms is low. More specifically, compliance was found inadequate concerning regarding hand hygiene guidelines, use of gloves when exposure to body fluids was anticipated, eye protection, mouth and nose protection (mask use), wearing a gown when required , avoid recapping the needle after it was used for a patient, and provision of care considering all patients as potentially infectious $^{(22-25)}$. 
Several factors ranging from personal to organizational causes were contributed to non-compliance with Standard Precautions among health care providers due to lack of knowledge, lack of time, forgetfulness, lack of means, negative influence of the equipment on nursing skills, uncomfortable equipment, skin irritation, lack of training, conflict between the need to provide care and self-protection and distance to necessary equipment or facility ${ }^{(26-30)}$.The costs of infection control and staffing are less when compared to that of HCAI. Therefore, nurses and student nurses should have professional and ethical responsibilities to make sure that their knowledge and skills regarding infection control standard precautions are up-to-date and they always practice safely and competently (31). Thus, education about infection prevention and control was targeted as one of the main objectives of the infection control programs especially where nurses represent the largest group of workers within the healthcare system ${ }^{(32,33)}$. Nursing student should be able to provide carefor patients after learning the principles of standard precautions, effective training is essential to ensure that these concepts about standard precautions are understood and put into practice wherever health care is provided (34). Nurses are expected to perform all functions necessary for the total patients care. They must know how to protect others from contacting infection, and she is responsible for disseminating prevention and control information to personnel, patients, their community members ${ }^{(35)}$.Nursing students play a critical role in the prevention efforts so, they are an important population needed to study their level of knowledge, attitudes, and behavior regarding infection control measures, and obtaining this information are useful for developing programs to improve their performance ${ }^{(36,37)}$. Studies on standard precautions are increasing over the world $(7,8,11,14)$, however there has been limited attention paid to investigate nursing students' understanding and compliance regarding standard precautions within certain localities. Therefore, the purpose of the present study was to assessthe knowledge and compliance of nursing students regarding infection control standard precautions during their clinical training.

\section{Aim of the study:}

The aim of the present study was to assessknowledge and compliance of nursing students regarding infection control standard precautions during their clinical training. 


\section{Research questions:}

-What are the nursing students' knowledge and compliance about standard precautions?

-What are the factors affecting nursing students' knowledge and compliance with infection control standard precautions?

\section{Subjects and method:}

\section{Study Design: -}

An analytic comparative study was used to conduct this study.

\section{Study settings: -}

The study was conducted during students clinical training at medical surgical, obstetric and gynecological departments in Faculty of Nursing and Tanta university hospital as well as maternal and child health care centers $(\mathrm{MCH})$.

\section{Study subjects: -}

Data were collected over a period of three months from the beginning of March to the end of May during the second semester of the academic year 2018-2019. A proportion simple random sample of $25 \%$ of the total faculty studentswhich constituted 450students were enrolled and willing to participate in the study.

\section{Tools of the study: -}

Two tools were used in this study.

Tool (I): Structured questionnaire sheet. It was divided into twoparts: -

\section{Part}

(1)

Socio-demographic

characteristics which included age, sex, residence, academic year, working beside the study and source of information.

\section{Part (2): Knowledge of students about standard precautions: -}

To gather data, the researchers adopted the questionnaires developed by Tavolacci etal., $(2008)^{(38)}$.Standard precautions knowledge questions included the basic concepts, content, and activity requirements of the standard precautions, which covering 18 items, with possible responses of 'yes', 'no', or 'unknown'. 'Yes' is given a value of 1 point(if Yes is correct answer); and 'No' or 'Unknown' 0 points in some items and 'No' is given a value of 1 point, and 'Yes ' 0 points in some items(if No is correct answer); the maximum possible score is 18 . The total score ranged from zero to 18 . The higher the score, the greater assumed knowledge about standard precautions the participant studentshave. Result of test was interpreted as follows; equal or more than (13.5)constituted "good knowledge" which is $(\geq 75 \%)$, from $11.7-13.5$ constituted "fair knowledge" which is $(65 \%$ to $<75 \%)$ and fromzero to less than 11.7 constituted "poor knowledge which is $(<65 \%)$. The higher participants score means greaterknowledge about standard precautions of infection control. 
Tool II: Compliance with standard precautions of infection control: -It included two parts.

Part (1): Compliance with standard precautions was measured by adapted the standard precautions questionnaires developed by Luo et al., (2010) ${ }^{(39)}$.One item on compliance questionnaire was removed, since students are not yet allowed to perform venous puncture. The Arabic translated version of compliance questionnaire was validated for its reliability resulting in statistical value of 0.78 (Cronbach's alpha). There are 17 compliance items with a scale of $0-2$ points: $0=$ never, $1=$ sometimes and $2=$ always, giving a score range of $0-34$. In determining the level of compliance, the following scaling was used; for good compliance more than 25.5 which equal $\geq$ $75 \%$, satisfactory compliance more than 25.5 to less than 22.1 which equal from $65 \%$ to $<75 \%$, poorcompliance less than 22.1 which equal $<65 \%$. The higher the mean score, the better that student carries out the standard precautions.

\section{Part (2): Factors affecting the} compliance with standard precautions $(40,41)$ : -

Factors affecting the compliance with standard precautions were measured by the tool developed by the researchers according to literature review. This part covered two factors affecting the compliance with standard precautions: patient's type covered by four standard items as (children, foreigners irrespective of age, patient's personal characteristics irrespective of age and adults) as well as activity's type (situation) covered by sixteen standard items as (physician way of working/ demand, wrong routine practice at workplace, patient discomfort, embarrassment, reminding for using precautions, lack of time, time consuming, negative impact on nurse, equipment not immediately available, emergency situations, colleagues with more experience, previous exposure, protection offered by precautions, cost from being infected, fear and death) .There were 20 items with a scale of 1-3 points: $1=$ less effect, $2=$ moderate effect and $3=$ more effect, itwas giving a score ranged of 2060. Total score of patient' type was categorized as follows: less than 9 refers to less effect, 9 moderate effect, and 10 and above more effect, while total score of activity' type (situation) categorized less than 37 less effect, 37-39 moderate effect, and 40 and above more effect.

\section{Methods:}

1- Before conducting the study, an official permission to carry out the study was secured through an official letter to deans of the Faculty of 
Nursing Tanta University explaining the purpose of the research to get the permission for data collection.

2- Ethical considerations: - Students' oral consent was obtained, rights, anonymity and confidentiality of the respondents were respected in all phases of the study and all students were informed about the purpose and the benefits from this study.

3- The structured questionnaire sheet was developed based on literature review and was translated into Arabic version by the researchers.

4- Before embarking on actual study, the knowledge questionnaire and the compliance were used in a pilot test student on fifty students before being distributed to the students enrolled in this research and those students were excluded from the study. Refinement and modifications were done on the basis of pilot study results.

5- The researcher asked the students regarding compliance items during their clinical training ( at medical and surgical units, obstetric and gynecological units including antenatal, labor and delivery unit as well as postpartum unit and operation room in cesarean section also in maternal and child health care centers $(\mathrm{MCH})$.
6- The researcher asked the students on application of infection control standard precautions which are the minimum infection prevention practices that applied to all patient care, regardless of suspected or confirmed infection status of the patient including ( hand hygiene, use of personal protective equipment's, (e.g., gloves, mask, eye wear), respiratory hygiene/ cough etiquette, safe injection practices(i.e., aseptic technique for parenteral medications), sterile instruments and devices as well as clean disinfected environmental surfaces) .

7-Validity test: The tool of data collection was distributed to a jury of 5 academic professors in Community Health Nursing Department, Maternity and Gynecological Nursing Department, and Medical and Surgical Nursing Department to test its face and content validity. Accordingly, corrections and modifications were done. The validity of the expertise judgments of the questions of the Arabic translated version of standard precautions knowledge was 0.98 .

8-The reliability of the translated Arabic tool was done by using Cronbach's Alpha which was0.87. 


\section{9- Statistical analysis}

The data were coded, entered and analyzed using SPSS (version 20). Descriptive statistics (frequency numbers Percentages and $X^{2}$ identified demographic characteristics and students' responses to the questionnaire. Paired $\mathrm{t} / \mathrm{F}$ tests were used to analyze the relationships; statistically significant was set at $\mathrm{P}$ value $<$ $0.05 \%$. Spearman correlation was used to examine the correlations between Knowledge and reported compliance total scores.

\section{Results:}

Table (1): Represents distribution of the studied subjects according to their sociodemographic data. This table shows that the means of ages of the studied students were $20.21 \pm 0.619, \quad 21.67 \pm 1.047$, and $21.74 \pm 0.65$ years for second, third and fourth academic years respectively. More than three quarters $(76.7 \%)$ and two thirds $(64.0 \%)$ of students in the second and fourth year of students respectively were female, while more than half $(50.7 \%)$ of students in third year were male. In relation to residence more than half (56.7 $\%)$, majority of students (84.7\%) and more than three thirds $(67.3 \%)$ of students in the second, third and fourth year respectively were lived in rural. In relation to working beside the study $(91.3 \%, 60 \%$ and $78.7 \%)$ of students in the second, third and fourth years were not working beside the study.

Table (2): Shows distribution of the studied subjects according to their source of knowledge. The table reveals that high percent of students their source of knowledge were lectures $(61.3 \%, 76 \%$ and $73.3 \%$ respectively) in the second, thirdand fourth-years students and there were statistical significance difference $\mathrm{P}<0.05$. While low percent of students their sources of knowledge were hospital guidelines (8.7 $\%, 10 \%$ and $29.3 \%$ respectively) in the second, third- and fourth-year students, meanwhile there was statistical significance difference.

Table (3): Represents the mean scores of knowledge domains about infection control among studied subjects. The table shows that there was statistical significance difference between the three years students in relation to all knowledge domains about infection control standard precautions except for body fluid $\mathrm{P}<0.05$. The total mean scores of knowledge were (13.04 $\pm 3.072, \quad 13.55 \pm 1.144, \quad$ and $12.24 \pm 2.579)$ respectively.

Table (4): Represents the mean scores of domains of compliance with slandered precaution about infection control among studied groups. The table shows that there were statistically significant differences in relation to syringe and sharp disposal $\mathrm{P}<$ 
0.05 and the total mean score in the studied group were $30.91 \pm 5.844,30.75 \pm 3.183$ and $29.67 \pm 5.142$ for the second, third and fourth years of students respectively.

Table (5): Represents the studied groups according to patient's type factors affecting the compliance with standard precaution. There was statistical significance difference between the three studied groups in relation to patient's type factors (children, foreigners, patient's personal characteristics and adults) affecting the compliance with standard precaution $\mathrm{P}<$ 0.05 .

Table (6): Represents distribution of the studied subjects according to activity's type (situation) factors affecting the compliance with standard precautions. This table showed that there was statistical significance difference between the three studied subjects of students in relation to activity's type (situation) factor affecting the compliance with standard precautions $\mathrm{P}<0.05$.

Table (7): Represents distribution of the studied subjects according to their levels of knowledge and compliance. This table shows that high percent of students had good level of knowledge $64.7 \%, 75.3 \%$ and $39.3 \%$ in the second, third and fourth years respectively. Also majority $(89.3 \%$, $94.7 \%$ and $82.7 \%$ respectively) of the studied groups (second, third and fourth years) had good practice score of compliance, also there was statistical significance difference between levels of scores of knowledge and also between levels of scores of compliance $\mathrm{P}<0.05$.

Table (8) and figure (1): Show the comparison between the studied groups according to total score of patient's type and activity's factors affecting the compliance with standard precautions. In relation to total score of patient's type there were high percent of students in the second and fourth years had more effect $50.7 \%$ and $43.3 \%$ respectively. Also, in relation to total score of activity's factors high percent $51.3 \%$ and $68 \%$ in the second and fourth year of students respectively had less effect. There was statistical significance difference in the three studied groups.

This table (9): Shows comparison between level of knowledge and compliance among the studied subjects. The table shows that there was statistically significance difference in relation to total score of knowledge and compliance score in the three studied years. The majority (97.9\%, $96.5 \%$ and $94.9 \%)$ of students with good compliance score had good knowledge score respectively. 
Table (1): Distribution of the studied subjects according to their socio-demographic data

\begin{tabular}{|c|c|c|c|c|c|c|c|}
\hline \multirow{2}{*}{\multicolumn{2}{|c|}{ Socio-demographic data }} & \multicolumn{2}{|c|}{$2^{\text {nd }} \operatorname{Year}(n=150)$} & \multicolumn{2}{|c|}{$3^{\text {rd }} \operatorname{Year}(n=150)$} & \multicolumn{2}{|c|}{$\begin{array}{ll}4^{\text {th }} & \text { Year } \\
(n=150) & \\
\end{array}$} \\
\hline & & $\mathrm{N}$ & $\%$ & $\mathrm{~N}$ & $\%$ & $\mathrm{~N}$ & $\%$ \\
\hline \multirow{3}{*}{$\begin{array}{l}\text { Age } \\
\text { (years) }\end{array}$} & $=<21$ & 148 & 98.7 & 73 & 48.7 & 55 & 36.7 \\
\hline & $>21$ & 2 & 1.3 & 77 & 51.3 & 95 & 63.3 \\
\hline & $\begin{array}{l}\text { Range } \\
\text { Mean } \pm \text { SD }\end{array}$ & \multicolumn{2}{|c|}{$\begin{array}{l}22-19 \\
20.21 \pm 0.619\end{array}$} & \multicolumn{2}{|c|}{$\begin{array}{l}23-20 \\
21.67 \pm 1.047\end{array}$} & \multicolumn{2}{|c|}{\begin{tabular}{|l|}
$24-21$ \\
$21.74 \pm 0.65$ \\
\end{tabular}} \\
\hline \multirow{2}{*}{ Sex } & Male & 35 & 23.3 & 76 & 50.7 & 54 & 36.0 \\
\hline & Female & 115 & 76.7 & 74 & 49.3 & 96 & 64.0 \\
\hline \multirow{2}{*}{ Residence } & Rural & 85 & 56.7 & 127 & 84.7 & 101 & 67.3 \\
\hline & Urban & 65 & 43.3 & 23 & 15.3 & 49 & 32.7 \\
\hline \multirow{2}{*}{$\begin{array}{l}\text { Working } \\
\text { beside } \\
\text { study }\end{array}$} & No work & 137 & 91.3 & 90 & 60.0 & 118 & 78.7 \\
\hline & private hospital & 13 & 8.7 & 60 & 40.0 & 32 & 21.3 \\
\hline
\end{tabular}

* Significant at level $\mathrm{P}<0.05$

Table (2): Distribution of the studied subjects according to their source of knowledge

\begin{tabular}{|c|c|c|c|c|c|c|c|c|}
\hline \multicolumn{2}{|l|}{ Source of knowledge } & \multicolumn{2}{|c|}{$\begin{array}{l}2^{\text {nd }} \text { Year } \\
(n=150)\end{array}$} & \multicolumn{2}{|c|}{$\begin{array}{l}3^{\text {rd }} \text { Year } \\
(n=150)\end{array}$} & \multicolumn{2}{|c|}{$\begin{array}{l}4^{\text {th }} \quad \text { Year } \\
(n=150)\end{array}$} & \multirow[t]{2}{*}{$\begin{array}{l}\chi^{2} \\
\mathbf{P}\end{array}$} \\
\hline & & $\mathrm{N}$ & $\%$ & $\mathrm{~N}$ & $\%$ & $\mathrm{~N}$ & $\%$ & \\
\hline \multirow{2}{*}{ 1. Lectures } & no & 58 & 38.7 & 36 & 24.0 & 40 & 26.7 & \multirow{2}{*}{$\begin{array}{l}8.757 \\
0.013 *\end{array}$} \\
\hline & yes & 92 & 61.3 & 114 & 76.0 & 110 & 73.3 & \\
\hline \multirow{2}{*}{ 2. Self-learning } & no & 92 & 61.3 & 116 & 77.3 & 87 & 58.0 & \multirow{2}{*}{$\begin{array}{l}14.191 \\
0.001 *\end{array}$} \\
\hline & yes & 58 & 38.7 & 34 & 22.7 & 63 & 42.0 & \\
\hline \multirow{2}{*}{ 3. Clinical practices } & no & 102 & 68.0 & 82 & 54.7 & 89 & 59.3 & \multirow{2}{*}{$\begin{array}{l}5.755 \\
0.056\end{array}$} \\
\hline & yes & 48 & 32.0 & 68 & 45.3 & 61 & 40.7 & \\
\hline \multirow{2}{*}{ 4. Work shops } & no & 136 & 90.7 & 122 & 81.3 & 128 & 85.3 & \multirow{2}{*}{$\begin{array}{l}5.392 \\
0.067\end{array}$} \\
\hline & yes & 14 & 9.3 & 28 & 18.7 & 22 & 14.7 & \\
\hline \multirow{2}{*}{ 5. Hospital guidelines } & no & 137 & 91.3 & 135 & 90.0 & 106 & 70.7 & \multirow{2}{*}{$\begin{array}{l}29.861 \\
0.00 *\end{array}$} \\
\hline & yes & 13 & 8.7 & 15 & 10.0 & 44 & 29.3 & \\
\hline
\end{tabular}

Vol. $20 \quad$ No. 1(Suppl) February 2021 
Table (3): Mean scores of knowledge domains about infection control standard among studied subjects

\begin{tabular}{|c|c|c|c|c|}
\hline \multirow[t]{2}{*}{ Knowledge domains } & $2^{\text {nd }}$ Year $(n=150)$ & $3^{\text {rd }} \operatorname{Year}(n=150)$ & $\begin{array}{l}4^{\text {th }} \text { Year } \\
(n=150)\end{array}$ & \multirow[t]{2}{*}{$\begin{array}{l}\mathbf{F} \\
\mathbf{P}\end{array}$} \\
\hline & Mean \pm SD & Mean \pm SD & Mean \pm SD & \\
\hline $\begin{array}{l}\text { 1. Hospital } \\
\text { environment and } \\
\text { health workers } \\
\end{array}$ & $4.19 \pm 1.325$ & $4.77 \pm 0.607$ & $4.20 \pm 1.253$ & $\begin{array}{l}13.199 \\
0.00 *\end{array}$ \\
\hline 2. Hand washing & $1.89 \pm 0.550$ & $2.02 \pm 0.357$ & $1.81 \pm 0.621$ & $\begin{array}{l}6.415 \\
0.002 *\end{array}$ \\
\hline $\begin{array}{l}\text { 3. Protective } \\
\text { clothes }\end{array}$ & $3.24 \pm 1.294$ & $2.93 \pm 0.493$ & $2.65 \pm 1.069$ & $\begin{array}{l}12.960 \\
0.00 *\end{array}$ \\
\hline 4. Body fluids & $3.72 \pm 0.963$ & $3.84 \pm 0.676$ & $3.59 \pm 1.177$ & $\begin{array}{l}2.609 \\
0.075\end{array}$ \\
\hline $\begin{array}{l}\text { Total knowledge } \\
\text { score }\end{array}$ & $13.04 \pm 3.072$ & $13.55 \pm 1.144$ & $12.24 \pm 2.579$ & $\begin{array}{l}11.331 \\
0.00 *\end{array}$ \\
\hline
\end{tabular}

* Significant at level $\mathbf{P}<0.05$

Table (4): Mean scores of domains ofcompliance with standard precaution about infection control among studied subjects

\begin{tabular}{|l|l|l|l|l|}
\hline $\begin{array}{l}\text { Domains of compliance } \\
\text { with } \begin{array}{l}\text { standard } \\
\text { precaution }\end{array}\end{array}$ & $\begin{array}{l}\mathbf{2}^{\text {nd }} \\
\text { Year(n=150) }\end{array}$ & $\mathbf{3}^{\text {rd }}$ Year(n=150) & $\mathbf{4}^{\text {th }}$ Year(n=150) & F \\
\cline { 2 - 5 } & Mean \pm SD & Mean \pm SD & Mean \pm SD & \\
\hline 1. Hand washing & $5.39 \pm 1.098$ & $5.54 \pm 0.701$ & $5.39 \pm 1.016$ & $\begin{array}{l}1.182 \\
0.308\end{array}$ \\
\hline 2. Wearing gloves & $16.61 \pm 3.258$ & $16.19 \pm 2.002$ & $15.94 \pm 2.745$ & $\begin{array}{l}2.30 \\
0.101\end{array}$ \\
\hline $\begin{array}{l}\text { 3. Protective clothes } \\
\text { (mask, eye, gown) }\end{array}$ & $5.33 \pm 1.408$ & $5.49 \pm 0.903$ & $5.15 \pm 1.271$ & $\begin{array}{l}2.965 \\
0.053\end{array}$ \\
\hline $\begin{array}{l}\text { 4. Syringe and sharp } \\
\text { disposal }\end{array}$ & $3.57 \pm 0.870$ & $3.53 \pm 0.841$ & $3.19 \pm 1.039$ & $\begin{array}{l}\mathbf{8 . 0 0 3} \\
\mathbf{0 . 0 0} *\end{array}$ \\
\hline Total compliant score & $\mathbf{3 0 . 9 1 \pm 5 . 8 4 4}$ & $\mathbf{3 0 . 7 5} \pm \mathbf{3 . 1 8 3}$ & $\mathbf{2 9 . 6 7 \pm 5 . 1 4 2}$ & $\begin{array}{l}2.908 \\
0.056\end{array}$ \\
\hline
\end{tabular}

* Significant at level $\mathbf{P}<0.05$ 
Table (5): Distribution of the studied subjects according to patient's type factor affecting the compliance with standard precautions

\begin{tabular}{|c|c|c|c|c|c|c|c|c|}
\hline \multirow{2}{*}{\multicolumn{2}{|c|}{ Patient's type }} & \multicolumn{2}{|c|}{$\begin{array}{l}2^{\text {nd }} \text { Year } \\
(n=150)\end{array}$} & \multicolumn{2}{|c|}{$\begin{array}{l}3^{\text {rd }} \text { Year } \\
(n=150)\end{array}$} & \multicolumn{2}{|c|}{$\begin{array}{l}4^{\text {th }} \quad \text { Year } \\
(n=150)\end{array}$} & \multirow{2}{*}{$\begin{array}{l}\chi^{2} \\
\mathbf{P}\end{array}$} \\
\hline & & $\mathrm{N}$ & $\%$ & $\mathrm{~N}$ & $\%$ & $\mathrm{~N}$ & $\%$ & \\
\hline \multirow[t]{3}{*}{ 1. Children } & Less effect & 26 & 17.3 & 27 & 18.0 & 33 & 22.0 & \multirow{3}{*}{$\begin{array}{l}192.5 \\
0.00^{*}\end{array}$} \\
\hline & Moderate effect & 22 & 14.7 & 123 & 82.0 & 38 & 25.3 & \\
\hline & More effect & 102 & 68.0 & - & - & 79 & 52.7 & \\
\hline \multirow{3}{*}{ 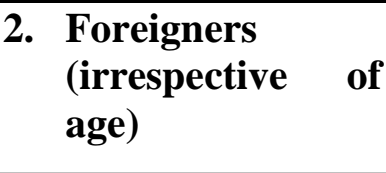 } & Less effect & 23 & 15.3 & 4 & 2.7 & 22 & 14.7 & \multirow{3}{*}{$\begin{array}{l}98.931 \\
0.00 *\end{array}$} \\
\hline & Moderate effect & 73 & 48.7 & 146 & 97.3 & 79 & 52.7 & \\
\hline & More effect & 54 & 36.0 & - & - & 49 & 32.7 & \\
\hline \multirow{3}{*}{$\begin{array}{l}\text { 3. Patient's } \\
\text { personal } \\
\text { characteristics } \\
\text { (irrespective of } \\
\text { age) }\end{array}$} & Less effect & 42 & 28.0 & 32 & 21.3 & 27 & 18.0 & \multirow{3}{*}{$\begin{array}{l}62.535 \\
0.00 *\end{array}$} \\
\hline & Moderate effect & 69 & 46.0 & 118 & 78.7 & 77 & 51.3 & \\
\hline & More effect & 39 & 26.0 & - & - & 46 & 30.7 & \\
\hline \multirow[t]{3}{*}{ 4. Adults } & Less effect & 23 & 15.3 & 33 & 22.0 & 30 & 20.0 & \multirow{3}{*}{$\begin{array}{l}143.1 \\
0.00^{*}\end{array}$} \\
\hline & Moderate effect & 35 & 23.3 & 117 & 78.0 & 51 & 34.0 & \\
\hline & More effect & 92 & 61.3 & - & - & 69 & 46.0 & \\
\hline
\end{tabular}

* Significant at level $\mathbf{P}<0$.

Table (6): Distribution of the studied subjects according to activity's type (situation) factors affecting the compliance with standard precautions

\begin{tabular}{|c|c|c|c|c|c|c|c|c|}
\hline \multicolumn{2}{|c|}{ Situation } & \multicolumn{2}{|c|}{$\begin{array}{l}2^{\text {nd }} \text { Year } \\
(\mathrm{n}=150)\end{array}$} & \multicolumn{2}{|c|}{$\begin{array}{l}\mathbf{3}^{\text {rd }} \text { Year } \\
(\mathrm{n}=150)\end{array}$} & \multicolumn{2}{|c|}{$\begin{array}{l}4^{\text {th }} \text { Year } \\
(n=150)\end{array}$} & \multirow{2}{*}{$\begin{array}{l}\chi^{2} \\
\mathbf{P}\end{array}$} \\
\hline & & $\mathrm{N}$ & $\%$ & $\mathrm{~N}$ & $\%$ & $\mathrm{~N}$ & $\%$ & \\
\hline \multirow{3}{*}{$\begin{array}{l}\text { Physicians' way of } \\
\text { working/demands }\end{array}$} & Less effect & 36 & 24.0 & 61 & 40.7 & 40 & 26.7 & \multirow{3}{*}{$\begin{array}{l}133.3 \\
0.00^{*}\end{array}$} \\
\hline & Moderate effect & 23 & 15.3 & 89 & 59.3 & 53 & 35.3 & \\
\hline & More effect & 91 & 60.7 & - & - & 57 & 38.0 & \\
\hline \multirow{3}{*}{$\begin{array}{llr}\text { 2. } & \text { Wrong routine } \\
\text { practice } & \text { at } \\
\text { workplace }\end{array}$} & Less effect & 28 & 18.7 & 36 & 24.0 & 38 & 25.3 & \multirow{3}{*}{$\begin{array}{l}131.0 \\
0.00 *\end{array}$} \\
\hline & Moderate effect & 35 & 23.3 & 114 & 76.0 & 63 & 42.0 & \\
\hline & More effect & 87 & 58.0 & - & - & 49 & 32.7 & \\
\hline \multirow{3}{*}{$\begin{array}{ll}\text { 3. } & \text { Patient } \\
\text { discomfort }\end{array}$} & Less effect & 57 & 38.0 & 20 & 13.3 & 55 & 36.7 & \multirow{3}{*}{$\begin{array}{l}99.117 \\
0.00 *\end{array}$} \\
\hline & Moderate effect & 57 & 38.0 & 130 & 86.7 & 58 & 38.7 & \\
\hline & More effect & 36 & 24.0 & - & - & 37 & 24.7 & \\
\hline \multirow[t]{3}{*}{ 4. $\quad$ Embarrassment } & Less effect & 40 & 26.7 & 34 & 22.7 & 40 & 26.7 & \multirow{3}{*}{$\begin{array}{l}51.992 \\
0.00 *\end{array}$} \\
\hline & Moderate effect & 69 & 46.0 & 116 & 77.3 & 83 & 55.3 & \\
\hline & More effect & 41 & 27.3 & - & - & 27 & 18.0 & \\
\hline \multirow{3}{*}{$\begin{array}{ll}\text { 5. } & \text { Reminding for } \\
\text { using } \\
\text { precautions }\end{array}$} & Less effect & 51 & 34.0 & 34 & 22.7 & 45 & 30.0 & \multirow{3}{*}{$\begin{array}{l}81.454 \\
0.00 *\end{array}$} \\
\hline & Moderate effect & 48 & 32.0 & 116 & 77.3 & 72 & 48.0 & \\
\hline & More effect & 51 & 34.0 & - & - & 33 & 22.0 & \\
\hline 6. Lack of time & Less effect & 40 & 26.7 & 19 & 12.7 & 41 & 27.3 & 106.3 \\
\hline
\end{tabular}

Vol. 20 No. 1 (Suppl) February, 2021 


\begin{tabular}{|c|c|c|c|c|c|c|c|c|}
\hline & Moderate effect & 51 & 34.0 & 131 & 87.3 & 69 & 46.0 & \multirow[t]{2}{*}{$0.00 *$} \\
\hline & More effect & 59 & 39.3 & - & - & 40 & 26.7 & \\
\hline \multirow{3}{*}{$\begin{array}{ll}\text { 7. } & \text { Time } \\
\text { consuming }\end{array}$} & Less effect & 35 & 23.3 & 23 & 15.3 & 35 & 23.3 & \multirow{3}{*}{$\begin{array}{l}118.4 \\
0.00^{*}\end{array}$} \\
\hline & Moderate effect & 45 & 30.0 & 127 & 84.7 & 59 & 39.3 & \\
\hline & More effect & 70 & 46.7 & - & - & 56 & 37.3 & \\
\hline \multirow{3}{*}{$\begin{array}{ll}\text { 8. } & \begin{array}{l}\text { Negative } \\
\text { impact } \\
\text { nurse }\end{array} \\
\end{array}$} & Less effect & 40 & 26.7 & 32 & 21.3 & 47 & 31.3 & \multirow{3}{*}{$\begin{array}{l}119.3 \\
0.00^{*}\end{array}$} \\
\hline & Moderate effect & 39 & 26.0 & 118 & 78.7 & 73 & 48.7 & \\
\hline & More effect & 71 & 47.3 & - & - & 30 & 20.0 & \\
\hline \multirow{3}{*}{$\begin{array}{l}\text { 9. Equipment not } \\
\text { immediately } \\
\text { available }\end{array}$} & Less effect & 32 & 21.3 & 49 & 32.7 & 37 & 24.7 & \multirow{3}{*}{$\begin{array}{l}122.6 \\
0.00 *\end{array}$} \\
\hline & Moderate effect & 33 & 22.0 & 101 & 67.3 & 70 & 46.7 & \\
\hline & More effect & 85 & 56.7 & - & - & 43 & 28.7 & \\
\hline \multirow{3}{*}{$\begin{array}{l}\text { 10. Emergency } \\
\text { situation }\end{array}$} & Less effect & 43 & 28.7 & 39 & 26.0 & 32 & 21.3 & \multirow{3}{*}{$\begin{array}{l}144.7 \\
0.00^{*}\end{array}$} \\
\hline & Moderate effect & 21 & 14.0 & 111 & 74.0 & 68 & 45.3 & \\
\hline & More effect & 86 & 57.3 & - & - & 50 & 33.3 & \\
\hline \multirow{3}{*}{$\begin{array}{l}\text { 11. Colleagues with } \\
\text { more } \\
\text { experience }\end{array}$} & Less effect & 49 & 32.7 & 37 & 24.7 & 46 & 30.7 & \multirow{3}{*}{$\begin{array}{l}99.555 \\
0.00 *\end{array}$} \\
\hline & Moderate effect & 40 & 26.7 & 113 & 75.3 & 58 & 38.7 & \\
\hline & More effect & 61 & 40.7 & - & - & 46 & 30.7 & \\
\hline \multirow{3}{*}{$\begin{array}{l}\text { 12. Previous } \\
\text { exposure }\end{array}$} & Less effect & 45 & 30.0 & 38 & 25.3 & 39 & 26.0 & \multirow{3}{*}{$\begin{array}{l}103.2 \\
0.00 *\end{array}$} \\
\hline & Moderate effect & 38 & 25.3 & 112 & 74.7 & 62 & 41.3 & \\
\hline & More effect & 67 & 44.7 & - & - & 49 & 32.7 & \\
\hline \multirow{3}{*}{$\begin{array}{l}\text { 13. Protection } \\
\text { offered by } \\
\text { precautions }\end{array}$} & Less effect & 41 & 27.3 & 34 & 22.7 & 44 & 29.3 & \multirow{3}{*}{$\begin{array}{l}82.080 \\
0.00 *\end{array}$} \\
\hline & Moderate effect & 55 & 36.7 & 116 & 77.3 & 60 & 40.0 & \\
\hline & More effect & 54 & 36.0 & - & - & 46 & 30.7 & \\
\hline \multirow{3}{*}{$\begin{array}{l}\text { 14. Cost from } \\
\text { being infected }\end{array}$} & Less effect & 42 & 28.0 & 28 & 18.7 & 32 & 21.3 & \multirow{3}{*}{$\begin{array}{l}103.3 \\
0.00 *\end{array}$} \\
\hline & Moderate effect & 43 & 28.7 & 122 & 81.3 & 75 & 50.0 & \\
\hline & More effect & 65 & 43.3 & - & - & 43 & 28.7 & \\
\hline \multirow[t]{3}{*}{ 15. Fear } & Less effect & 24 & 16.0 & 38 & 25.3 & 31 & 20.7 & \multirow{3}{*}{$\begin{array}{l}109.8 \\
0.00 *\end{array}$} \\
\hline & Moderate effect & 46 & 30.7 & 112 & 74.7 & 62 & 41.3 & \\
\hline & More effect & 80 & 53.3 & - & - & 57 & 38.0 & \\
\hline \multirow[t]{3}{*}{ 16. Death } & Less effect & 36 & 24.0 & 53 & 35.3 & 35 & 23.3 & \multirow{3}{*}{$\begin{array}{l}85.226 \\
0.00 *\end{array}$} \\
\hline & Moderate effect & 49 & 32.7 & 97 & 64.7 & 59 & 39.3 & \\
\hline & More effect & 65 & 43.3 & - & - & 56 & 37.3 & \\
\hline
\end{tabular}

* Significant at level $\mathbf{P}<0.05$

Table (7): Distribution of the studied subjects according to their levelsof knowledge and compliance

\begin{tabular}{|c|c|c|c|c|c|c|c|c|}
\hline \multicolumn{2}{|c|}{ Levels of knowledge and compliance } & \multicolumn{2}{|c|}{$\begin{array}{l}2^{\text {nd }} \text { Year } \\
(n=150)\end{array}$} & \multicolumn{2}{|c|}{$\begin{array}{l}3^{\text {rd }} \text { Year } \\
(n=150)\end{array}$} & \multicolumn{2}{|c|}{$\begin{array}{l}4^{\text {th }} \text { Year } \\
(n=150)\end{array}$} & \multirow{2}{*}{$\begin{array}{l}\chi^{2} \\
P\end{array}$} \\
\hline & & $\bar{N}$ & $\%$ & $\overline{\mathrm{N}}$ & $\%$ & $\overline{\mathrm{N}}$ & $\%$ & \\
\hline \multirow{3}{*}{$\begin{array}{c}\text { Total knowledge } \\
\text { score }\end{array}$} & Poor & 31 & 20.7 & 17 & 11.3 & 42 & 28.0 & \multirow{3}{*}{$\begin{array}{c}44.923 \\
0.00 *\end{array}$} \\
\hline & Fair & 22 & 14.7 & 20 & 13.3 & 49 & 32.7 & \\
\hline & Good & 97 & 64.7 & 113 & 75.3 & 59 & 39.3 & \\
\hline \multirow{3}{*}{$\begin{array}{c}\text { Total } \\
\text { compliance score }\end{array}$} & Poor compliance & 12 & 8.0 & 2 & 1.3 & 18 & 12.0 & \multirow{3}{*}{$\begin{array}{l}14.803 \\
0.005 *\end{array}$} \\
\hline & $\begin{array}{l}\text { Satisfactory } \\
\text { compliance }\end{array}$ & 4 & 2.7 & 6 & 4.0 & 8 & 5.3 & \\
\hline & Good compliance & 134 & 89.3 & 142 & 94.7 & 124 & 82.7 & \\
\hline
\end{tabular}

* Significant at level $\mathbf{P}<0.05$

Vol. 20 No. 1 (Suppl) February, 2021 
Table (8): Comparison between the studied subjects according to total score of patient's type and total activity's factor affecting their compliance with standard precautions

\begin{tabular}{|c|c|c|c|c|c|c|c|c|}
\hline \multirow{2}{*}{\multicolumn{2}{|c|}{$\begin{array}{l}\text { Total score of patient's type and total } \\
\text { activity's factors }\end{array}$}} & \multicolumn{2}{|c|}{$\begin{array}{l}2^{\text {nd }} \text { Year } \\
(n=150)\end{array}$} & \multicolumn{2}{|c|}{$\begin{array}{l}3^{\text {rd }} \text { Year } \\
(n=150)\end{array}$} & \multicolumn{2}{|c|}{$\begin{array}{l}4^{\text {th }} \quad \text { Year } \\
(n=150)\end{array}$} & \multirow{2}{*}{$\begin{array}{l}\chi^{2} \\
\mathbf{P}\end{array}$} \\
\hline & & $\mathrm{N}$ & $\%$ & $\mathrm{~N}$ & $\%$ & $\mathrm{~N}$ & $\%$ & \\
\hline \multirow{3}{*}{$\begin{array}{l}\text { 1. Total score } \\
\text { of patient's } \\
\text { type }\end{array}$} & Less effect & 58 & 38.7 & 150 & 100 & 60 & 40.0 & \multirow{3}{*}{$\begin{array}{l}\text { 157.1 } \\
0.00 *\end{array}$} \\
\hline & Moderate effect & 16 & 10.7 & - & - & 25 & 16.7 & \\
\hline & More effect & 76 & 50.7 & - & - & 65 & 43.3 & \\
\hline \multirow{3}{*}{$\begin{array}{l}\text { 2. Total score } \\
\text { of activity' } s \\
\text { factors }\end{array}$} & Less effect & 77 & 51.3 & 150 & 100 & 102 & 68.0 & \multirow{3}{*}{$\begin{array}{l}103.8 \\
0.00 *\end{array}$} \\
\hline & Moderate effect & 19 & 12.7 & - & - & 24 & 16.0 & \\
\hline & More effect & 54 & 36.0 & - & - & 24 & 16.0 & \\
\hline
\end{tabular}

* Significant at level $\mathbf{P}<\mathbf{0 . 0 5}$.

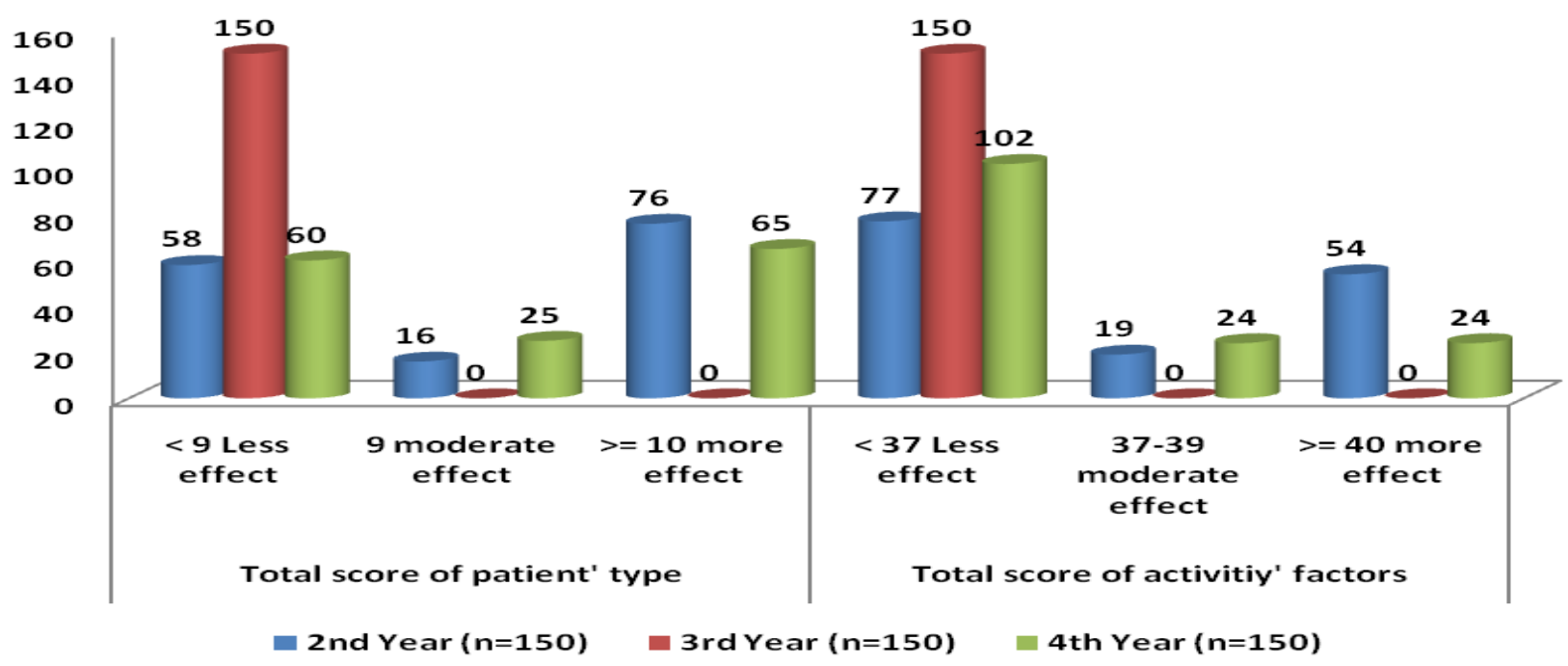

Figure (1): Comparison between the studied subjects according to total score of patient's type and activity's factor affecting the compliance with standard precautions 
Table (9): Comparison between level of knowledge and compliance among the studied subjects

\begin{tabular}{|c|c|c|c|c|c|c|c|c|c|c|}
\hline \multirow{3}{*}{\multicolumn{2}{|c|}{$\begin{array}{l}\text { Total compliance } \\
\text { Score }\end{array}$}} & \multicolumn{6}{|c|}{ Total knowledge score } & \multirow{2}{*}{\multicolumn{2}{|c|}{ Total }} & \multirow{3}{*}{$\begin{array}{l}\chi^{2} \\
\mathbf{P}\end{array}$} \\
\hline & & \multicolumn{2}{|c|}{ Poor } & \multicolumn{2}{|c|}{ Fair } & \multicolumn{2}{|c|}{ Good } & & & \\
\hline & & $\mathbf{N}$ & $\%$ & $\mathbf{N}$ & $\%$ & $\mathbf{N}$ & $\%$ & $\mathbf{N}$ & $\%$ & \\
\hline \multirow{3}{*}{$2^{\text {nd }}$ year } & Poor compliance & 12 & 38.7 & - & - & - & - & 12 & 8.0 & \multirow{4}{*}{$\begin{array}{l}53.663 \\
0.00 *\end{array}$} \\
\hline & $\begin{array}{l}\text { Satisfactory } \\
\text { compliance }\end{array}$ & 2 & 6.5 & - & - & 2 & 2.1 & 4 & 2.7 & \\
\hline & Good compliance & 17 & 54.8 & 22 & 100 & 95 & 97.9 & 134 & 98.3 & \\
\hline \multicolumn{2}{|l|}{ Total } & 31 & 100 & 22 & 100 & 97 & 100 & 150 & 100 & \\
\hline \multirow{3}{*}{$3^{\text {rd }}$ year } & Poor compliance & - & - & - & - & 2 & 1.8 & 2 & 1.3 & \multirow{4}{*}{$\begin{array}{l}19.762 \\
0.001 *\end{array}$} \\
\hline & $\begin{array}{l}\text { Satisfactory } \\
\text { compliance }\end{array}$ & 4 & 23.5 & - & - & 2 & 1.8 & 6 & 4.0 & \\
\hline & Good compliance & 13 & 76.5 & 20 & 100 & 109 & 96.5 & 142 & 94.7 & \\
\hline \multicolumn{2}{|l|}{ Total } & 17 & 100 & 20 & 100 & 113 & 100 & 150 & 100 & \\
\hline \multirow{3}{*}{$4^{\text {th }}$ year } & Poor compliance & 16 & 38.1 & 1 & 2.0 & 1 & 1.7 & 18 & 12.0 & \multirow{4}{*}{$\begin{array}{l}40.334 \\
0.00 *\end{array}$} \\
\hline & $\begin{array}{l}\text { Satisfactory } \\
\text { compliance }\end{array}$ & 1 & 2.4 & 5 & 10.2 & 2 & 3.4 & 8 & 5.3 & \\
\hline & Good compliance & 25 & 59.5 & 43 & 87.8 & 56 & 94.9 & 124 & 82.7 & \\
\hline \multicolumn{2}{|l|}{ Total } & 42 & 100 & 49 & 100 & 59 & 100 & 150 & 100 & \\
\hline
\end{tabular}

Significant at level $P<0.05$ 


\section{Discussion:}

Hospital acquired infection is a common problem all over the world. Therefore, up to date knowledge and refined practical nursing skills can play an important role in preventing infection. Infection Control (IC) is evidence-based practices and procedures that, when applied consistently in healthcare settings which can prevent or reduce the risk of microorganism's transmission to the healthcare providers, other patients and visitors. Nursing student should have the opportunity to practice infection control on a day-to-day basis as an integral part of patient care ${ }^{(2-6)}$. So, this study was carried to assess knowledge and compliance of nursing students regarding infection control standard precautions during their clinical training.

The findings of the current study revealed that, the studied sample age ranged from 19 to 24 years old. This finding was in accordance with Sreedharan et al., (2011) $^{(40)}$,who studied knowledge about standard precautions among university hospital nurses in the United Arab Emirates. On the other hand, Labrague et al., (2012) ${ }^{(9)}$, found in their study about knowledge and compliance with standards precautions that the mean age was slightly lesser than the current study. From the researcher point of view the younger age of the studied sample increases their ability to acquire up to date knowledge which in turn change their behaviors. In this regards Alwutaib et al., (2012) ${ }^{(41)}$, revealed that the older age is an important determinant of lower knowledge levels. Concerning gender, the current study demonstrated that more than three quarters and two third of students in the second and fourth academicyear respectively were female which show the dominance of females than males. This finding is in agreement with Labrague et al., (2012) ${ }^{(9)}$, Vaz et al., $(\mathbf{2 0 1 0})^{(7)}$, who revealed the dominance of females than male in their studied samples. In relation to residence the findings of the present study clarify that more than half, nearly three quarters of students and more than two third of students in the second, third and fourth year respectively lived in rural area. This finding is in accordance with that of Johnson et al., (2013) ${ }^{(42)}$, and Janjua et al., (2007) ${ }^{(43)}$, who declared that most of the studied sample were from rural residence. As regarding to working beside the study, the findings of this study illustrated that the majority of students in the second, third and fourth years were not working beside the study. Reda et al., (2010) ${ }^{(44)}$, also stated that most of the studied sample not working beside their study which emphasizing the need to 
protect this group in the prime of their life from hospital acquired infections.

In relation to students' sources of knowledge, the findings of the present study demonstrated that nearly three quarters of students in the third and fourth year, their source of knowledge were lectures. This was consistent with Reda et al., (2010) ${ }^{(44)}$, who found that most students agreed that current curriculum provides them with enough information on IC and SPs. Also agreed about the role of their tutors and faculty in providing them with necessary information on how to avoid health facilities related infections before their entrance into hospital clinical training. Furthermore, according to Tavolacci et al., (2008) (38), who announced that nurse educators may need to provide an environment that models and promotes standard precaution practices by positive role modeling.

Concerning levels of students' knowledge regarding infection control, the findings of the present study showed that high percent of students had good level of knowledge in the second, third and fourth years respectively. On the same line with this finding was Ibrahim et al., (2011) ${ }^{(15)}$, who found the majority of the studied group was aware with, what infection is, and how it is transmitted. In this regards Perry and Potter (2002) ${ }^{(45)}$ revealed that by understanding how infection is transmitted or spread, the nurse can intervene to prevent infections from developing. On the other hand, Qayyum et al., (2016) ${ }^{(2)}$ who found poor knowledge about nosocomial infections and their routes of spread among the studied sample. Concerning the group who obtained high knowledge scores in the current study, they were acquainted with sharp devices and needle stick injuries; personal protective equipment; hand hygiene; standard precaution and methods used to prevent infection. This of special concern especially where approximately one third of the studied sample attended training courses about infection control.

Concerning student's compliance regarding infection control standard precautions, it was found that majority of the studied groups (second, third and fourth years) stated that they had good practice score of compliance. This agreed with Talaat et al., (2006) ${ }^{(46)}$. From the researcher point of view this findings could be related to that compliance assessed from students perspectives and a further study need to be done to study compliance from the teacher perspectives as what nursing students do (application of infection control standard precautions) in the current study could be based on what explained by their lecturer (theoretical curriculum). In 
addition, the findings of the present study reflect the lecturer emphasis on following infection control precautions during clinical hospital training and constructive supervision by their demonstrators. In this regards Gijare, (2012) ${ }^{(47)}$, revealed that providing feedback is necessary to improve knowledge, attitude, practices and so compliance to infection control standard precautions.

On the other hand, Ibrahim et al., (2011) $^{(15)}$, who assessed infection control practices in a neonatal intensive care unit and emphasized the importance of compliance to infection control standards to reduce in-hospital neonatal morbidity and mortality. The same authors attributed that lack of compliance to infection control standards precaution due to lack of knowledge about standard procedures of infection control; poor design of the intensive care unit; high work load; lack of sustainable resources and arrangements; time of contacts (daytime or night shift), and lack of training and constructive supervision. Therefore, efforts are needed to correct unacceptable nurses' performance, especially where certain mismatching was noticed between what nurses know and what they do in the current study.

Regarding patient's type factors affecting the compliance with standard precaution.
There was statistical significance difference between the three studied groups in relation to patient's type factors (children, foreigners, patient's personal characteristics and adults) affecting the compliance with standard precaution $\mathrm{P}<$ 0.05. The findings of this study were in line with Bouchoucha et al., (2019) (48) who illustrated that identifying the factors that influence compliance with infection prevention and control practices (IPC) provides a foundation for developing adherence strategies. This study reinforces that nurses need to have more responsibility to enhance their compliance. Management support in hospitals to ensure enough staffing is necessary, in addition to having personal protective equipment readily available when needed. Nursing managers and IPC departments should monitor nurses in the performance of IPC practices and provide periodic feedback to encourage nurses' compliance.

In relation to activity's type (situation) factors affecting the compliance with standard precautions. It was found that there was statistical significance difference between the three studied subjects of students in relation to activity's type (situation) factor affecting the compliance with standard precautions $\mathrm{P}<0.05$. The findings of the present study was consistent with Zebet al., (2019) ${ }^{(49)}$ who 
demonstrated that factors affecting nurses compliance to SPs highlighted by participants in current study include, unavailability of resources like personalprotective equipment (PPEs) by $73.6 \%$, 55.7\%. Participants highlighted workload due to shortage of staff $75.8 \%$ elaborated unavailability and dissemination of infection control policies. Another study conducted by Efstathiouet al., (2011) (25) shows that workload, unavailability of equipment and patient's discomfort are the factors affecting Nurses compliance to SPs. Also Lack of facilities provision and maintenance, heavy workload andlack of good role models were factors determined by Hedayati et al., (2014) ${ }^{(50)}$, at a dental Schoolin Iran.

A statistically significant positive correlation was found between knowledge and compliance in the current study. This finding reflects that nursing students'compliance is based on their knowledge. In agreement with the current study finding was that of Gijare, (2012) (47), Hamid et al. (2010) ${ }^{(51)}$, and NdikomandOnibokun (2007) ${ }^{(52)}$,who revealed statistically significant positive correlation between knowledge and practice of universal precautions.

In contrast with the present study, Askarian et al. (2007) ${ }^{(53)}$, found no correlation between knowledge and practice regarding infection control. Also, Najeeb et al., (2008) ${ }^{(54)}$, reported a weak, negative relationship between knowledge and practice regarding infection control among nurses and doctors. This reflects the need for enhancing knowledge of all nursing qualification categories, which emphasize the need for continuous training programs about infection control to facilitate adherence to infection control measures. In this regardsRoyal College of Nursing (RCN),(2012) ${ }^{(31)}$,emphasized that workplaces should have written policies about methods of utilizing infection control standard precautions to provide guidance on all aspects of critically ill patients' care. As well, continuing education regardless of age can significantly improve infection control practices and reduces rates of infection.

\section{Conclusion and Recommendations:}

This study showed that there was statistically significance difference in relation to total score of knowledge and compliance score in the three studied years. However, teaching must be strengthened, particularly with respect to the concepts of hand hygiene and protective clothes where students scored less. Also,the periodic refresher training courses and regular lectures should be provided to nursing students in order to keep them of updating knowledge and 
practice regarding standard precaution measures. Future educational strategies to make changes in their behaviors maybe enhanced through intensive return demonstration of effective use of protective equipment such as masks and eye goggles, requiring students to submit written journal, nursing care plans (NCP's) and anecdotal record of demonstration and integration of standard precaution practices during clinical exposure.

\section{References:}

1. Nejad SB, Allegranzi B, Syed SB, Ellis B, Pittet D. Health-careassociated infection in Africa: A systematic review. Bulletin of the World Health Organization. 2011; 89(1):757-765.

2. Qayyum S, Sattar A,Waqas B. Hospital acquired infections; Knowledge about it and its prevention. Professional Med.J. 2010; 17(2):168173.

3. Sandokji AM, Murshid KR, El-Badry AA, Al-Ali AH,Shalaby SA.Infectious nosocomial diarrhea in the surgical wards: Role of Parasites and Microbes Imply Stool Analysis. Journal of Taibah University Medical Sciences. 2009; 4(1): $73-81$.

4. World Health Organization. Infection prevention and control in health care: Time for collaborative action.
Regional Committee for the Eastern Mediterranean.

Available from:https://apps.who.int/iris/handle/1 0665/122923.

5. UwaezuokeSN, Obu HA. Nosocomial infections in neonatal intensive care units: Cost-effective control strategies in resource-limited countries. Niger J. Paed. 2013; 40 (2): 125-132.

6. EltingLS, LuC,EscalanteCP. Outcomes and cost of outpatient or inpatient management of 712 patients with febrile neutropenia. J. Clin. Oncol. 2008; 26(1):606-611.

7. Vaz1 K, McGrowder D, AlexanderLindo R, Gordon L, Brown P, Irving R. Knowledge, awareness and compliance with universal precautions among health care workers at the university hospital of the West Indies, Jamaica.Int J Occup Environ Med. 2010; 1 (4):171-181. Available from:https://pubmed.ncbi.nlm.nih.gov/ 23022806/

8. Siegel JD, RhinehartE, Jackson M, Chiarello L. Healthcare Infection Control Practices Advisory Committee. Guideline for isolation precautions: Preventing transmission of infectious agents in healthcare settings. Centers for Disease Control.2007. Available from: 
9. Labrague LJ, Rosales RA, Tizon MM. Knowledge of and compliance with standard precautions among student nurses. International Journal of Advanced Nursing Studies.2012; 1 (2): 84-97.

10. Holla R, Kanchan T, Kumar N, Unnikrishnan B, Rekha T, MithrA P, et al. Perception and practices of standard precautions among health care professionals at Tertiarycare Hospitals in Coastal South India.Asian J. Pharm Clin Res. 2014;7(2): 101104.

11. Garner JS. Hospital Infection Control Practices Advisory Committee. Guideline for isolation precautions in hospitals. Infect Hosp Epidemiol.1996;17:53-80.

12. Abdulraheem IS, Amodu MO, Saka MJ, Bolarinwa OA, Uthman MM. Knowledge, awareness and compliance with standard precautions among health workers in North EastearnNigeria.Community Medicine \& Health Education. 2012;2(3):1-5

13. Bouallègue $O$, Naija $W$, Said $H$, Nouria A, Jaidane N, DhidahL, et al. Incidence of ICU acquired nosocomial infections in University Hospital of Sahloul (Sousse-Tunisia). Antimicrobial Resistance and Infection Control.2013; 2(1): 233.
14. Eskander HG, Morsy WY, Elfeky HA. Intensive care nurses' knowledge \&practices regarding infection control standard precautions at a selected Egyptian Cancer Hospital. Journal of Education and Practice. 2013; 4(19):160-174.

15. Ibrahim YS, Said AM, Hamdy GK. Assessment of infection control practices in neonatal intensive care unit. The Egyptian Journal of Community medicine. 2011; 29(4):2745.

16. Ministry of Health and Population General Directorate of Quality (GDQ). Standards for Primary Health Care Centers and Units. 2007.

17. Pittet D, HugonnetS ,Harbarth S. Effectiveness of a hospital-wide program to improve compliance with hand hygiene. Lancet. 2000; 356(9238):1307-1312.

18. Hugonnet S, Chevrolet J,PittetD. The effect of workload on infection risk in critically ill patients. Crit. Care Med. 2007; 35(1):76-81.

19. Haynes RB, Sackett DL, Taylor DW. Compliance in health care Baltimore: John Hopkins University Press; 1979. Available from:https://www.worldcat.org/title/co mpliance-in-health-care/oclc/4493661 
20. Ogden J. Helath Psychology: a Textbook. 4th ed. Buckingham: Open University Press; 2007. Page

21. Hazavehei SM, Taghdisi MH,Saidi M. Application of the Health Belief Model for osteoporosis prevention among middle school girl students, Garmsar, Iran. Educ Health (Abingdon). 2007; 20(1):23.

22. Stein AD, Makarawo TP, Ahmad MF. A survey of doctors' and nurses' knowledge, attitudes and compliance with infection control guidelines in Birmingham teaching hospitals. J. Hosp.Infect.2003; 54(1):68-73.

23. Pan A, Domenighini F, Signorini L, Assini R, Catenazzi P, Lorenzotti S, et al. Adherence to hand hygiene in an Italian long-term care facility. Am J. Infect Control. 2008; 36(7):495-497.

24. Nichol K, Bigelow P, O’Brien-Pallas L, McGeer A, Manno M,Holness DL. The individual, environmental, and organizational factors that influence nurses' use of facial protection to prevent occupational transmission of communicable respiratory illness in acute care hospitals. Am J. Infect Control. 2008; 36(7):481-487.

25. Efstathiou G, PapastavrouE, Raftopoulos V,MerkourisA.Factors influencing nurses' compliance with standard precautions in order to avoid occupational exposure to microorganisms: A focus group study. $\mathrm{BMC}$ Nursing. 2011;10:1.https://doi.org/10.1186/147 2-6955-10-1

26. Sax H, Perneger $T$, Hugonnet $S$, Herrault P, Chraiti MN, PittetD.Knowledge of standard and isolation precautions in a large teaching hospital. Infect Control Hosp Epidemiol. 2005; 26(3):298-304.

27. Oliveira AC, Cardoso CS, Mascarenhas D. Contact precautions in intensive care units: Facilitating and inhibiting factors for professionals' adherence. Rev. Esc EnfermUSP. 2010; 44(1):161-165.

28. Whitby M, McLaws ML, RossMW.Why healthcare workers don't wash their hands: A behavioral explanation. Infect Control Hosp Epidemiol. 2006; 27(5):484-492.

29. Sax H, Uckay I, Richet H, Allegranzi B,Pittet D. Determinants of good adherence to hand hygiene among healthcare workers who have extensive exposure to hand hygiene campaigns. Infect Control Hosp.Epidemiol.2007;28(11):12671274.

30. Doi SA, Amigo MF. Nurses' intentions to wear gloves during venipuncture procedures: A behavioral 
psychology perspective. Infect Control

Hosp. Epidemiol. 2007; 28(6):747750.

31. Royal College of Nursing. Essential practice for infection prevention and control Guidance for nursing staff, London: RCN. 2012. Publication code: 004 166. Available from:

32. https://issuu.com/nhskirklees/docs/ess ential_practice_for_infection_preventi on_and_co.

33. Rasslan O. Infection Prevention and Control Education in Egypt: Professional Diploma in Infection Control (PDIC). Int. J. Infect. Control. 2011; $\quad 7(2)$ doi: 10.3396/ijic.V7i2.015.11.

34. World Health Organization (WHO). Hepatitis B. [Cited 15 Dec 2009.] Available from URL: http://www.who.int/mediacentre/ factsheets/fs204/en/. 2008.

35. Dehkordi L M,Tavakol K. Experiences of nursing students in caring of patients in Source Isolation. Iran J Nurs Midwifery Res Winter. 2011; 16(1):16-23.

36. Al Yousef SA. Effect of nursing guidelines regarding infection control measures on performance of Internship Students in applied Medical Science College at Hafr Al-Batin.
IOSR Journal of Nursing and Health Science (IOSR-JNHS). 2014;3(4):37-46.

37. Nobile C G, Montuori P, Diaco E, Villari P. Health care personnel andhand decontamination in Intensive Care Units: Knowledge, attitude and behavior in Italy. Hospital Infection. 2002;51(3):226-232.

38. Chan M F, Day M C. Investigating the knowledge, attitudes and practice patterns of operating room staff towards standard and transmissionbasedprecautions: Results of A Cluster Analysis. J. Clin.Nurs. 2008; 17: 1051-1062.

39. Tavolacci M P, Ladner J, Bailly L, Merle V, Pitrou I, Czernichow P. Prevention of nosocomial infection and standard precautions: Knowledge and source of information among healthcare students. Infection Control and Hospital Epidemiology. 2008; 29(7): 642-647.

40. Luo Y, He G-P, Zhou JW, Luo Y. Factors impacting compliance with standard precaution in nursing, China. International Journal of Infectious Diseases, 2010; 14(12):1106-1114. Available from: http://dx.doi.org/ 10.1016/j.ijid.2009.03.037.

41. Sreedharan J, Muttappillymyalil J, Venkatramana M.Knowledge about standard precautions among university 
hospital nurses in the United Arab Emirates. Eastern Mediterranean Health Journal.2011;17 (4): 331-334.

42. Alwutaib AH, Abdulghafour YA, Alfadhli AK, Makboul G, El-Shazly MK. Knowledge and attitude of the physicians and nurses regarding blood borne infections in primary health care, Kuwait. Greener Journal of Medical Sciences. 2012;2(4): 107-114. 43. JohnsonK. Infection Control Curriculum Module.Center for Aide Regulation and Education. North Carolina Department of Health \& Human Services 2000. cite 10-122013 Available from: www.ncdhhs.gov.

44. Janjua NZ, Razaq M, ChandirS. Poor knowledge--predictor of nonadherence to universal precautions for blood borne pathogens at first level care facilities in Pakistan. BMC Infect Dis.2007; 7:81

45. Reda AA, Frisseha S, Mengistie B, Vanderweerd J. Standard precautions: Occupational exposure and behavior of health care workers in Ethiopia. Plos One.2010;5 (12): e14420.

46. Perry AG, Potter PA. Clinical nursing skills techniques. 5th Ed, St. Louis: Mosby co.;2002.924-928.

47. TalaatM, Kandeel A, RasslanO, Hajjeh R, Hallaj Z, El-Sayed N, et al.
Evolution of infection control in Egypt: Achievements and challenges. Major article. Amer. J. Infect. Contr. 2006;34(4):193-200.

48. Gijare M. Effectiveness of teaching on infection control practices among health care professionals. Sinhgad e Journal of Nursing.2012;2(2): 5-9.

49. Bouchoucha S L, Moore K A. Factors influencing adherence to standard precautions scale: A psychometric validation. Nursing \& Health Sciences. 2019;21, 178- 185.

50. Zeb A. Factors affecting nurses' compliance to standard precautions in resource scarce settings. Am J. Biomed Sci.\& Res. 2019; 4(5): 384389.

DOI:

\subsection{7/AJBSR.2019.04.000840}

51. Hedayati H, Marjadi B, Askarian M. Barriers to standard precautions adherence in a dental school in Iran: A qualitative study. Am J. Infect Control.2014;42(7): 750-704.

52. Hamid MZ, Aziz NA, Anita AR, Norlijah O. Knowledge of bloodborne infectious diseases and the practice of universal precautions amongst health-care workers in a tertiary hospital in malaysia. Southeast Asian J. Trop Med Public Health. 2010;41(5): 1192-1199. 
53. Ndikom C M, Onibokun A. Knowledge and behavior of nurses/widwives in the prevention of vertical transmission of HIV in Owerri, Imo, Nigeria: A crosssectional study. Journal of Bio-Medical Center Nursing. 2007;1: 1-9.

54. Askarian M, McLaws ML, Meylan M. Knowledge, attitude and practices related to standard precautions of surgeons and physicians in universityaffiliated hospitals of Shiraz, Iran. Int. J. Infect Dis.2007;11: 213-9.

55. Najeeb N, Taneepanichsakul S. Knowledge, attitude, and practice of standard and transmission-based precautions of doctors and nurses in tertiary and secondary health care settings of Maldives. Journal of Health Research. 2008;22: 45-48. 